International Organizations and the Promotion of Gender Political ...

Dr. Nihal Shimy Abdel Fattah El-Shimy

\title{
International Organizations and the Promotion of Gender Political and Economic Equality in Egypt : The Role of UN Women and USAID
}

\author{
Dr. Nihal Shimy Abdel Fattah El-Shimy \\ PhD in International Relations \\ Modern Sciences and Arts University, Egypt (MSA)
}

\section{$\underline{\text { Abstract: }}$}

During the last six years, women played a primary role in shaping the country's political and economic realities and have strongly participated in their country's goals of development and social justice. Despite that, Egypt ranks low in terms of gender equality as women have lower participation in the work force and lower literacy rate. In other words, Egypt is a country with a very high rate of gender discrimination.

In the meantime, there is a belief that empowering women and having them integrated as active participants in the economy of the country is an essential factor to promote Egypt's economic growth. The increase of female participation in the labor force is essential for the increase of the GDP.

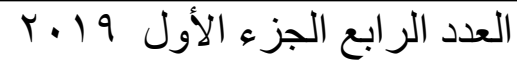

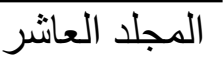


International Organizations and the Promotion of Gender Political ...

Dr. Nihal Shimy Abdel Fattah El-Shimy

Therefore, international organizations including UN Women and USAID are seeking to improve Egyptian women's status and decrease the gap between men and women. In other words, the programs of UN Women and USAID are actively involved with sectors in the Egyptian government to empower women and remove all kinds of constraints to their economic participation. They aim to improve skills, decrease illiteracy rate among women and raise women's participation rate in the work force.

Key Terms: Women, Empowerment, UN Women, US AID, Gender Equality, Economic Development, political participation, Feminist Theory, Developmental Theory, Conflict Theory

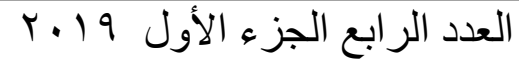
المجلد العاثر 
International Organizations and the Promotion of Gender Political ...

Dr. Nihal Shimy Abdel Fattah El-Shimy

\section{Introduction:}

There is a worldwide belief that that empowering women and having them integrated as active participants in the economy of a country is an important factor to promote the economic growth of the country. Thus, the decrease of illiteracy rate between females, and the increase of their participation in the labor force is essential for the increase of the GDP of any nation.

Therefore, international organizations including UN Women and USAID are seeking to improve women's status and decrease the gap between men and women in different parts of the world including Egypt. In other words, the programs of UN Women and USAID are actively involved with sectors in the various governments to empower women and remove all kinds of constraints to their economic participation. They aim to improve skills, decrease illiteracy rate among women and raise women's participation rate in the work force.

"Women's empowerment has five components: women's sense of self-worth; their right to have and to determine choices; their right to have access to opportunities and resources; their right to have the power to control their own lives, both within and outside the home; and their ability to influence the direction

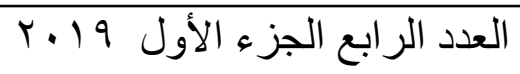

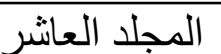


International Organizations and the Promotion of Gender Political ...

Dr. Nihal Shimy Abdel Fattah El-Shimy

of social change to create a more just social and economic order, nationally and internationally". (1)

Therefore, in the International Conference on Population and Development, the General Assembly Resolution 49/128 invites the UN organs and the specialized agencies to adopt actions that can give effective and full support to the implementation of the program. Thus, women empowerment is to be pursued within the coordination system of the UN, led by the Resident Coordinator to successfully implement the Program of Action. (2)

Policies of empowerment are impeded by the lack and insufficiency of information about women at the national and international levels. Thus, it is important to have a common gender data base and statistics available to all agencies of the UN and US AID. "This disaggregation is vital to follow-up actions targeted at the well- being of girls, adolescents and women and to identify areas in the life-cycle of women during which gender disparities are greatest". (3)

Since the 1990s, there has been more recognition and awareness of the importance of the empowerment of women to the success of programs of development. The appreciation and consideration of women's role in the process of development has been reflected in the priorities and goals of agencies in the United

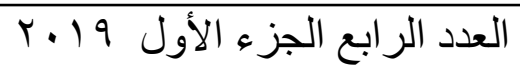$$
\text { المجلد العانشر }
$$ 
International Organizations and the Promotion of Gender Political ...

Dr. Nihal Shimy Abdel Fattah El-Shimy

Nations. In the Program of Action of the International Conference on Population and Development, emphasis is made on the autonomy and empowerment of women and the advancement and enhancement of their social, economic, political roles as well as their health status as a necessity to achieve sustainable human development. Moreover, it states that "Advancing gender equality and equity and the empowerment of women, and the elimination of all kinds of violence against women, and ensuring women's ability to control their own fertility ...are priority objectives of the international community" (4)

The Program of Action also foresees that women everywhere have to face threats to their health, lives and well being. As women get less education than men, and are represented among the powerless and poor, their status needs to be improved through policies and program actions. Such actions aim to improve their access to the valued and scarce resources, especially economic resources and secure livelihoods, improve their disproportionate household responsibilities and abolish social and legal obstacles to their participation in the public areas. They can also eliminate sexual harassment and violence from their daily lives and increase social awareness through programs of mass communication and education.

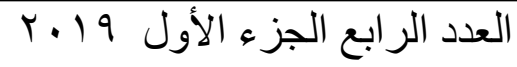

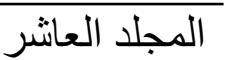


International Organizations and the Promotion of Gender Political ...

Dr. Nihal Shimy Abdel Fattah El-Shimy

Therefore, this study seeks to investigate how international organizations, basically UN Women and USAID, collaborate with the state to promote the rights of Egyptian women in political participation and economic as well as social issues. Also, focus will be made on measures taken to narrow the gender gap between males and females in work and all forms of right that human beings are entitled to enjoy.

\section{Research Significance:}

The researcher believes this topic is significant for the following reasons:

1. As a result of the global changes taking place, and the lack of opportunities for women in many countries, it seems appropriate to study the notion of gender inequality in more details with a special focus on the role of women in Egypt, and how their status can be improved to match their counterparts in many other countries of the world.

2. To study the extent to which some of the international organizations, for example UN Women and U.S. aid, in collaboration with the Egyptian government tend to focus on gender equality and find solutions to narrow the gap..

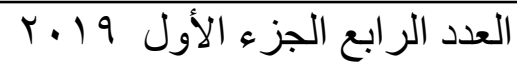
المجلد العاشر 
International Organizations and the Promotion of Gender Political ...

Dr. Nihal Shimy Abdel Fattah El-Shimy

3. The availability of primary sources from the UNDP and USAID, as well as periodicals and books written by international scholars is very tempting and encouraging to work on this particular topic.

4. Also, the researcher herself is an Egyptian woman who aspires for equal economic opportunities and political rights without any form of gender discrimination or a perception of inferiority to women.

The major hypothesis of this study: If some serious measures are followed by different agencies in collaboration with the Egyptian government to narrow down gender inequality in Egypt, then the percentage of illiteracy rate of women will decrease, and their contribution in business will definitely raise, which will have profound outcomes on the economy and social development as a whole.

\section{Hypothesis:}

1. There is a positive correlation between the role played by international organizations and the promotion of economic and political gender equality in Egypt.

2. The obstacles in achieving political and economic gender equality are basically due to the limited access to unbiased information.

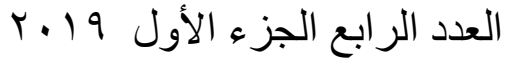

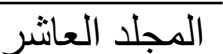


International Organizations and the Promotion of Gender Political ...

Dr. Nihal Shimy Abdel Fattah El-Shimy

3. The persistence of Egyptian traditions and norms whereby men are perceived as dominant and superior in all aspects is a major obstacle.

\section{Methodology and Theoretical Framework:}

As this study attempts to investigate the role played by international organizations in Egypt in promoting gender economic and political equality, and their collaboration the Egyptian government to achieve this goal, special focus is made on the factors that have strengthened this role as well as the obstacles that can hinder it. Gender equality has been an important goal, especially in the modern era, and this has preoccupied a number of international organizations for the last years. Thus, the idea of gender ism, and equal opportunities for both females and males will be studied, described, defined, analyzed, explained and evaluated in order to reach specific results. To do so, the researcher attempts to rely on two approaches:

- The Descriptive Approach is used to observe and describe the phenomena under discussion i.e. gender inequality and how it entails high illiteracy rate and low political and economic participation levels among women as compared to men. Thus, analysis are done

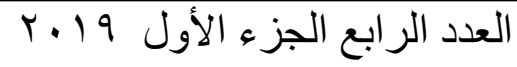

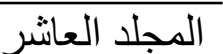


International Organizations and the Promotion of Gender Political ...

Dr. Nihal Shimy Abdel Fattah El-Shimy

according to observation, and then evaluation and predictions are made.

- The Normative Approach is also used to predict what should be done to solve the problem of gender inequality and what can be done about it.

\section{$\underline{\text { Data Collection: }}$}

The researcher mainly relies for data collection on information released by the United Nations and USAID. This was done purposely because the available data is current and sufficient, and they are considered primary sources as they are published by both organizations. Therefore, the researcher relies on the qualitative method of research in order to introduce new proofs and conclusions to the concept of gender equality, and how the UN Women and U.S. AID, in cooperation with the Egyptian government, attempt to improve women's economic and political status in Egypt in the coming era. Qualitative analysis in this context deals with intangible concerns that belong to the social integration of males and females. In addition to that, the key terms are defined and discussed in relation to the topic. Furthermore, the method of research used focuses on interpretation and tends to be subjective rather than objective.

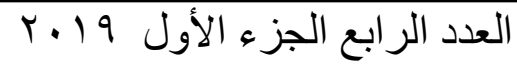

المجلد العاثر 
International Organizations and the Promotion of Gender Political ...

Dr. Nihal Shimy Abdel Fattah El-Shimy

\section{Theories Applied:}

1) Women Empowerment Theory:

Empowerment of women implies adopting measures to increase the degree of self determination and authority for girls and women and enable them to make and represent their own interests in self determined and responsible ways. Thus, by empowering women, they can transcend their lack of influence, overcome their sense of powerlessness and recognize their potentials. A number of literatures imply that certain factors can explain the increasing empowerment of women.

a) Socio-economic development, b) Increase of gender egalitarian attitudes which changes economic development into a form of cultural process of development of human beings. c) Legacies of history that stem and originate from the cultural and political traditions of society, and d)

Factors of institutional design. (5)

This research seeks to consider how the increase in gender egalitarian attitudes can change economic development in Egypt into a form of cultural process of development and progress of all society.

2) Development Theory:

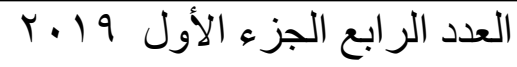

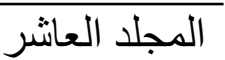


International Organizations and the Promotion of Gender Political ...

Dr. Nihal Shimy Abdel Fattah El-Shimy

This theory is concerned with how desirable change in society is achieved best. According to this theory, there are different approaches to development and therefore, various approaches to the subject. All approaches, however, are mainly concerned with the relationship between governance and development. "Development is usually seen as crucially determined by structures of governance; governance is interpreted through and shaped by the goal of development." (6)

This theory is used in this study to link development with national economic growth, in which women are a major factor. In this aspect, further development in Egypt may be achieved by overcoming gender differences in social, political, environmental and cultural spheres.

3) Feminist Theory:

The basic principle of feminist theory is the relationship between women and men has mostly been oppressive and unequal. All societies have had systems where males are dominated to females in all major social institution like political system, economy, family...etc. Thus, the theory of feminism is one that women and men must have equal economic political and social rights. Major areas of focus of this theory includes exclusion and discrimination "on the 
International Organizations and the Promotion of Gender Political ...

Dr. Nihal Shimy Abdel Fattah El-Shimy

basis of sex and gender, objectification structural and economic inequality, power and oppression, and gender roles and stereotypes, among others". (7)

This theory is very useful for this study, as it implies the importance of girls and women in economic growth, taking into account gender equality and non discriminatory measure on the basis of gender.

\section{4) Conflict Theory:}

Conflict theory implies that conflicts and tensions break out when power, status and resources are unevenly distributed between and among groups in a society, and that such conflicts and tensions become the engine and dynamo for social change. (8) This theory is used by the researcher to show how gender inequality, and the limited access of women in Egypt to resources and political and /or economic status can be the basis of conflict and unrest between the different social groups, and this can cause great future instability in the political system.

\section{Egypt and Gender Equality:}

Gender equality is defined by the United Nations International Cultural Educational Fund (UNICEF) as "leveling the playing field for girls and women by ensuring that all

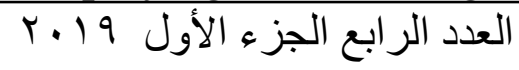
المجلد العاثر 
International Organizations and the Promotion of Gender Political ...

Dr. Nihal Shimy Abdel Fattah El-Shimy

children have equal opportunity to develop their talents." (9) Thus, the main question is whether Egyptian boys and girls have equal chances to develop their skills and talents. Debates about female's rights are not new, but have been around for a long time. Even now, there is no consensus or agreement on the role women must play in the society.

One can say that gender stereotypes in Egypt are both prescriptive and descriptive. They indicate what the majority of the people in Egypt believe how women and men must be like and the role each must play. Not only that, but Egyptian cultural institutions promote gender inequalities in portrayals of females and males. Thus, the nature of status beliefs in Egypt about women and men legitimizes a system where men enjoy more control than women in public domains and that includes professional settings. These widely held beliefs about control and the legitimacy of how control is distributed among men and women in Egypt serve to justify and maintain the current system. Thus, it can be said that in many domains in Egypt, men continue to surpass women in power and status. In Egypt, "The lack of fit" model between female stereotypic attributes and male gender typed job requirements leads to the conclusion that women in Egypt are not prepared to handle these jobs, and the expectation that they are not likely to succeed in positions that

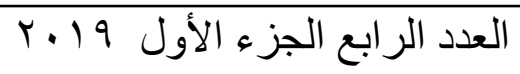$$
\text { المجلد العانشر }
$$ 
International Organizations and the Promotion of Gender Political ...

Dr. Nihal Shimy Abdel Fattah El-Shimy

are traditionally considered male. Such expectations of failure usually proceed to bias decisions of employment regarding women.

The researcher asked a number of girls with ages ranging between 18 and 22 about their opinion regarding the issue of gender inequality in Egypt. They were very concerned and critical about the issue and their answers came as follows: one girl (Marly Maged) said that Gender inequality in Egypt is a great social concern. The mentalities in society have imbalanced views about men and women. To empower and strengthen women, specialized schools should be established to prepare them for employability. Also, secondary schools should be renovated and built in numerous governments in Egypt to provide channels to prepare and expert improvement for both male and female educators. According to Areej Ayman, "Our society perceives women as the weaker sex." She believes this is a big mistake that needs to be corrected. She believes that initiatives and programs for awareness should be put in different places to keep Egyptian women safe and able to exercise their roles as citizens in a country where they are denied from their rights. "What's is needed is not just an attitude change, but a radical change of public thinking."

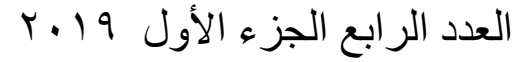

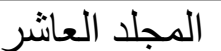


International Organizations and the Promotion of Gender Political ...

Dr. Nihal Shimy Abdel Fattah El-Shimy

The main problem is that in comparison with other states worldwide, Egypt ranks low in terms of gender equity. Therefore, Egypt is considered a country with a very high rate of gender inequality. The 2014 Human Development Report of the United Nations (EHDR) stated that the rank of Egypt on the Gender Equality Index is 130 among 187 states. Also, this report proclaimed that the majority of females in villages are illiterate. This has further health and social implications, not just for these women, but for the whole rural social fabric of the country. In the meantime, since females in villages don't get the primary compulsory education, parents don't bother to obtain birth certificates for their girls, and therefore, theoretically, those girls don't exist. (9) (KHALIFA) The results of the reports are based on four major pillars: educational attainment, survival and political empowerment, health and economic participation and opportunity. Such indicators reflect how equally the resources of the country are being distributed among and between genders.

All this has a negative impact on Egyptian women as they have a very low rate in political participation and in the work force. Also, their literacy rate is much less than that of men (women's literacy is $65 \%$ in comparison to males literary rate of $82 \%$.) Moreover, the participation of women in the labor force is significantly lower than men as their percentage is $26 \%$ in comparison to 79\% for men. (10) Moreover, in Egypt, millions of

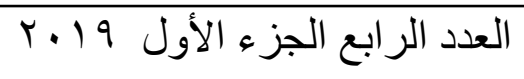

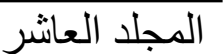


International Organizations and the Promotion of Gender Political ...

Dr. Nihal Shimy Abdel Fattah El-Shimy

poor women are not able to exercise their full citizenship, which includes voting and the application for government or private sector, social insurance, health...etc. (11) According to conservative estimates, at least two million Egyptian women are deprived of IDs, without which women are not entitled to vote and cannot have access to important state services such as social protection, education and health. Thus, a great number of eligible female voters are denied of their right to vote, and are kept in the dark. (12)

In the meantime, the participation of women in the Egyptian labor market is considered to be among the lowest in the world. For example, the percentage of young women aged between 18 and 29 constitute only $18.5 \%$ of the work force in Egypt, compared to more than $50 \%$ young men. (Arab states/North Africa) Although the informal sector represents the basic source of employment for the entrants of the new labor market, men working in the informal sector are either employers or wage workers, but women are basically non wage workers who contribute in different ways to a family business or household income. In other words, women in Egypt are constricted and undermined by social and cultural norms as well as conditions that make them poorer and less able to benefit from the protection and rewards of the labor markets. Also, they are

$$
\text { العدد الر ابع الجزء الأول } 9 \text { 1 • }
$$$$
\text { المجلد العاثر }
$$ 
International Organizations and the Promotion of Gender Political ...

Dr. Nihal Shimy Abdel Fattah El-Shimy

more burdened by the unpaid work which is often invisible and unsupported to the state as well as its social policies. In the meantime, Egypt is still striving to provide some specialized services that aim to support working women, such as accessible and affordable pre schools, or systems of home care for the sick or the elderly. (13)

\section{Political and Economic Participation of Women in Egypt Post 2011}

Since a long time, feminists, and women's rights groups have asked for fair representation in the positions of decision making. Before the 2011 revolution, some steps were taken by the government to consolidate the participation of women in the social, political and economic life of the country. However, measures taken to eliminate or reduce discrimination and strengthen female's political participation were minimal. For example, women nominated as candidates in 2008 for the local council election were not high, especially that only 2235 women were elected, and this made $4.4 \%$ of the number of local council members. The number of seats increased by 2009, as it increased to 518 from 454, which meant that women were able to get $12 \%$ of the number of seats. However, only 378 candidates out of 4000 were women in the 2010 parliamentary elections. (14)

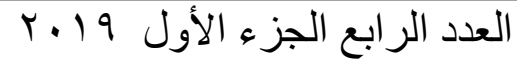

المجلد العاثر 
International Organizations and the Promotion of Gender Political ...

Dr. Nihal Shimy Abdel Fattah El-Shimy

The important role played by Egyptian women in the revolutionary movements of 2011, basically in January 25 and June 30, has been positively documented. The role of women in 2011 has given them more hope and let them claim their total rights as active participants in the Egyptian political life. "Nevertheless, women's status in Egypt has regressed in the realm of civil rights, freedoms and equal representation, especially after the Muslim brotherhood (MB) won the majority of Parliamentary seats and assumed most of the major offices in the Cabinet." 15)

However, after this, the status of Egyptian women has regressed in terms of freedoms, equal representation and civil rights. "Since 2011, the trend continued to be that of low representation for women; for instance, the Supreme Council of Armed Forces (SCAF) appointed an all-male committee to draft constitutional principles for a March referendum in 2011; no women have been able to become judges only since 2003, and no women is a public prosecutor. Moreover, there is no national strategy for gender equality." (16)

Despite that, groups of feminist and women's rights changed after the 2011 revolutions in various ways as new tools, such as direct interventions, new policy approaches and new media were used. In addition to that, the relationship between

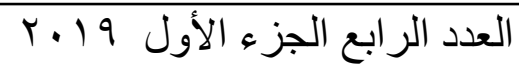

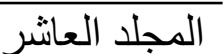


International Organizations and the Promotion of Gender Political ...

Dr. Nihal Shimy Abdel Fattah El-Shimy

feminist's situation in private and public spaces has been more linked in different actions and discourses. For example, various groups have been working on women's rights in private spaces, primarily with the focus of some political groups on the necessity of changing women laws made before 2011. (17) Also, since 2011, women human rights defenders (WHRDs) have increased due to the increase of violence against women in public space. Since sexual harassment is a very serious issue as sexual violence against women is a dangerous threat against females, on May $7^{\text {th }}$, 2015, a national strategy has been announced; one that aims to combat violence against females. (18)

Also, the issue of reform in Egypt and those of citizenship and democratization have been strongly placed on the agenda. Groups of feminist and women's rights relied mostly on legal tools that ranged from demonstrations made for equality rights and constitutional reform to guarantee equality, to demanding more representation in the decision making posts and elected bodies, which included local councils and parliament.

In other words, feminist groups strived to consolidate women's rights in such matters, but women representatives were not present in the first constitutional committee. In the second drafting, however, five women were on the committee and managed to establish some rights concerned with equality between men and women, and criminalized violence against

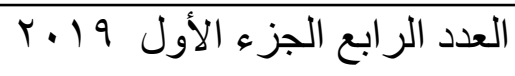

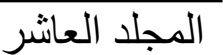


International Organizations and the Promotion of Gender Political ...

Dr. Nihal Shimy Abdel Fattah El-Shimy

women. Also, a commission was formed against discrimination, and aimed for equal and fair representation for women in various judicial and governmental bodies.

Therefore, a number of positive steps have already been taken in regards to women's political participation as the period between 2012 and 2014, has witnessed attempts to reform the constitution. By 2013, Egypt made a constitution that was amended in 2014 and granted women ten seats by nomination as specified by the president (without going through elections). Women were also given fifty six seats by one of the quotas prescribed by the constitution. Thus, according to the 2014 constitution, young people and women have a quota of twenty five percent reserved seats in the local councils. (19) In 2014, Egyptian women managed to get some gains and they became more aware in regards to who is to be elected. "The new constitution has paid a special attention to women, in both the preamble and the articles, stressing that women are not only part of the society, but they are half the society and the basis of the family, pointing at its active role and strong participation in the January 25 and June 30 revolution." (20) The constitution placed more emphasis on the notion of "citizenship", and on criminalizing and eliminating all types of discrimination. For example, article 9 states that the state has to guarantee all citizens equal chances without any form of discrimination.

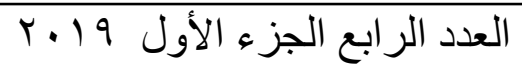$$
\text { المجلد العاثر }
$$ 
International Organizations and the Promotion of Gender Political ...

Dr. Nihal Shimy Abdel Fattah El-Shimy

Moreover, according to article 11, the state has to ensure the attainment of equality between men and women in all civic, economic, political, cultural and social rights in accordance with the terms of the constitution. Also, article 53 declares that all citizens are considered equal before the law. Thus, everyone, male or female, is equal in freedoms, rights, and responsibilities, with no discrimination based on belief, sex, religion, race, origin, color, social class, disability, geographic or political affiliation or any other cause. (21)

Also, the 2014 Law number 45 has strengthened and enforced women's quotas in parliamentary committees, and this was very clear in the initial results for the 2015 second stage of the Parliamentary elections which reflected the success of 87 female out of $596 \mathrm{MPs}$, thus representing 14.5 percent of the total number of seats. This step reflects a change in voting manners among women and men, and thus, represents a great step in the correct direction for equal representation of parliament. (22) For example, the number of female parliamentarians has reached $15 \%$ in 2017.

On the other hand, the economic empowerment of women is a process by which women can expand their capability to economically succeed and develop. It is widely believed that to empower Egyptian women and integrate them as active

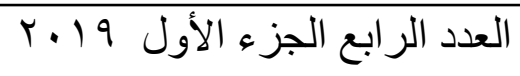$$
\text { المجلد العانشر }
$$ 
International Organizations and the Promotion of Gender Political ...

Dr. Nihal Shimy Abdel Fattah El-Shimy

participants in the system is important to promote the economic development of the country. The IMF further declares that to raise the participation rate of female labor to the equivalence of male level, along with access of opportunities of employment, will increase the GDP by about 34 percent. (23)

Unfortunately, an economic gender gap exists in Egypt as women participate in the economic sector with only $20.2 \%$ female workforce. Moreover, the majority of employed women are in the health and education sectors, and only $31.2 \%$ are of management positions. In addition to that, women get a low income if compared to men. "There is a consistent gap between women's wages and compensation in the public and private sector, with the latter lagging far behind the former. ( 24) Furthermore, women in the employment sector have to confront violence based on gender differences.

The Role of International Organizations in the Empowerment of Egyptian Women

Although there are several positive trends in equality of gender in Egypt, there are areas that still need to be considered. International organizations like UN Women and USAID encourage national partners to promote the progress towards equality of gender and women empowerment. They contribute to national results of development and the decrease of gender

$$
\text { العدد الرابع الجزء الأول } 9 \text { 1 • }
$$

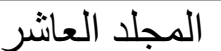


International Organizations and the Promotion of Gender Political ...

Dr. Nihal Shimy Abdel Fattah El-Shimy

differences. They collaborate with Egyptian agencies to ensure that women's voices are heard within institutions of government, the private sector and civil society and encourage equal participation with men in decision making and public dialogue. (25)

Thus, equality of gender is very important to the work of the UN and USAID in Egypt as they both believe that the empowerment of women is an integral and essential for the achievement of growth. Not only that, but it is the means for the attainment of the Sustainable Development Goals (SDGs)(26) The UNDP attempts to improve women's lives and their access to economic, social and legal rights. "The UNDP new sustainable Development Goals in the post 2015 recognizes this urgency, and foresees the necessity of an inclusive action plan in Egypt to raise awareness of the various indicators and targets involving women's wellbeing. There is also a need to decentralize mechanism on the governorate levels to better achieve them." (27)

In other words, USAID and other resources identify barriers to include the following:

- Cultural norms and values that discriminate against girls and women and restricts them in their economic endeavors

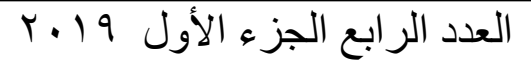

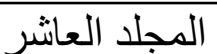


International Organizations and the Promotion of Gender Political ...

Dr. Nihal Shimy Abdel Fattah El-Shimy

- Lack of quality and affordable education, which results in illiteracy, poor quality or even non completion of education on the primary or secondary level

- lack of occupational or professional skills, any form of Gender based violence (GBV), and that includes domestic violence, sexual violence, violence in school based on gender, child marriage, labor abuse...etc.

- Political and Social marginalization due to ethnicity, age, religion, geography, marital status, health status, physical impairment...etc.

- Time poverty and immobility due to unpaid labor, high travel demands, child care responsibilities...etc.

- Environmental degradation, climate change, and natural disasters that may limit the access of women to quality and /or sufficient resources, that include natural resource and which can increase their time poverty and puts them at economic and personal risk

- Labor practices and laws which do not respect the rights of women, and this includes low pay, lack of childcare, lack of parental leave, lack of health...etc.

- Lack of political access or influence, and this includes limited access to national, regional or local government representatives and officials. It also includes lack of 
International Organizations and the Promotion of Gender Political ...

Dr. Nihal Shimy Abdel Fattah El-Shimy

voting ability or ID, limited knowledge of policies and laws, limited decision making power and restrictive customs or laws that can limit women's political participation,

- Non existence or low quality data on women and this implies the absence of big data on women, which inhibits development programs that require sufficient data

- Limited positions within value chains of the market, and this is mainly due to household care and duties

- Illiteracy, limited assets, limited language skills

- high costs of transportation, lack of information about the market in local language, lack of storage facilities

- Limited training in market regulations, financial management bargaining and leadership development. (28)

Therefore, UN Women and the USAID make policies and programs to support both national and international efforts to promote gender equality in Egypt. They believe that the development potential of a country cannot be achieved without the promotion of gender equality.

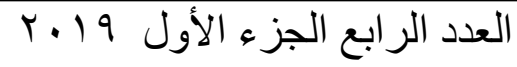
المجلد العاشر - n - n 
International Organizations and the Promotion of Gender Political ...

Dr. Nihal Shimy Abdel Fattah El-Shimy

\section{UN Women and Gender Equality in Egypt}

A campaign was launched by the National Council for Women in partnership of the United Nations Population Fund (UNFPA), the United Nations Development Program, UN Women and the Swedish Embassy. The campaign adopted the slogan, "The Taa' Marbouta is your strength." This implies how strong women should feel, and encourages them to break all types of barriers and obstacles that may stand in their way. A member of the National Council for Women, Rania Yahya said that the campaign "aims to deliver the voice of the Egyptian woman to various audiences, to encourage young women and to develop their spirit of determination and empower them." She further said that "The letter taa' marbouta [i.e., femininity] is the secret of women's strength and not their vulnerability." (29)

The UN Women contributes to improve gender responsive infrastructure which incorporates measures to ensure safety for women and girls. Also, UN Women supports the capacity of the agencies of the local government, along with women's organizations and civil society to respond and prevent sexual violence through knowledge, attitudes and skills. (30)

The UN Women have formed The Women's Political Empowerment Program for the 25th revolution's transitional and

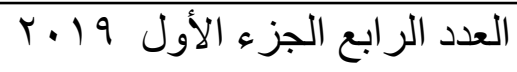

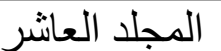


International Organizations and the Promotion of Gender Political ...

Dr. Nihal Shimy Abdel Fattah El-Shimy

post transitional phases. This program aims to assist the Egyptian government to carry the responsibilities it has in regards to gender equality under the various international declarations. Furthermore, it is considered a response to the challenges the country has to face in its transition towards a democratic system where women are strengthened and empowered to act and behave as equal citizens to males, and become more engaged in the different decision making levels in the private and public spheres. Furthermore, this program attempts to strengthen and consolidate women groups and civil society organizations for constitutional and legislative amendments that reflect an agenda of the rights of women, and also at the same time stress the ability of these organizations and groups to observe and watch women voters and candidates in the elections. (31)

As the UN Women Country Director for Egypt, Miwa Kato declared "Egyptian people have endured a lot of turmoil in a time of change. Women are playing a key role during the transition and UN Women is proud to be a supporter at every stage to make sure that the agenda of gender equality and women's empowerment makes it through as key priorities of the new Egypt" (32)

Kato also added that "Women are often projected as victims of society that have to be pitied and helped. This factor

$$
\text { العدد الرابع الجزء الأول } 9 \text { بـr }
$$$$
\text { المجلد العاثر }
$$ 
International Organizations and the Promotion of Gender Political ...

Dr. Nihal Shimy Abdel Fattah El-Shimy

undoubtedly remains and we need to redouble, triple our efforts to help victimized women. But at the same time, we need to project the strategic potential of empowering women, which is key to empowering Egypt," (33)

Therefore, UN Women in Egypt has been a very strong advocate for the securing of women's participation and equal rights in both the informal and formal economic sectors. UN Women is working on issues related to the creation of jobs as well as financial and non financial services that may enable women to have some kind of proper financial evaluation for their work in the agricultural sector. The program is focusing on access to credit, asset transfer and a saving scheme which will allow women to have: a) financial reward for their work, b). a feeling of economic security and c) the skills and the know how needed to run a business. (Arab states/North Africa) "When more women work, economies grow. An increase in female labour force participation — or a reduction in the gap between women's and men's labour force participation-results in faster economic growth." (34) "It is calculated that women could increase their income globally by up to 76 per cent if the employment participation gap and the wage gap between women and men were closed. This is calculated to have a global value of USD 17 trillion." (35)

العدد الرابع الجزء الأول 9 1 • المجلد العاثر 
International Organizations and the Promotion of Gender Political ...

Dr. Nihal Shimy Abdel Fattah El-Shimy

The UN women has greatly supported the positioning of girls and women through its initiatives and programs to reflect the idea that women and girls are a powerful and crucial part of achieving priority goals of the country in terms of social justice and inclusive growth, in addition to Sustainable Development Goals (SDGs)

In order for women to contribute to driving economic growth, UN Women is supporting women entrepreneurs and boosting the provision of access to assets, financial and non-financial services. UN Women has helped economically empower over 22,000 women and their extended families.

Also, UN Women is providing support for women entrepreneurs and provides access to assets as well as financial and non financial services.

In a closing remark, UN Women Country Director for Egypt, Miwa Kato said that "Women's empowerment and gender equality is one area where you can make a big difference in Egypt today, and this is the moment that we can and should support Egypt for a better future for Egyptian women and girls, men and boys," (36) Therefore, El Nidaa foundation helps assure sustainability, which is its main goal. It does so by providing the young men and women with needed skills to join the labor force, contribute to the country's economy and become entrepreneurs in the future.

$$
\text { العدد الرابع الجزء الأول } 9
$$


International Organizations and the Promotion of Gender Political ...

Dr. Nihal Shimy Abdel Fattah El-Shimy

\section{"Salheya": an Initiatives made by UN Women:}

An initiative called "Salheya" is as a chance to provide a model of demonstration for the strategy of integration for enhancing women's economic participation and for scaling up the equality of gender process. In partnership with the AUC Social Research Center and the Ministry of Man Power, the project seeks to consolidate the participation of the young unemployed women with medium and higher education in the economy and improve their rights and security.(37)

In its attempts to increase women's access to training, employment and career progress in private firms, the Gender Equity in Egypt (SEAL) is modeled and shaped according to the Mexico Gender Equity Project (Generosity) which has produced very encouraging results. In the meantime, activities have been made to meet the needs and realities of Egypt. SEAL is a process that firms choose if they seek to establish gender equity in the labor force. This includes four basic steps: a) self assessment, b) training, c) auditing and d) evaluation. "The application of this model makes it possible to visualize the inequalities of men and women within an organization in order to establish strategically linked equity measures through affirmative actions, whereby these inequalities are corrected and a satisfactory work environment and more motivated staff are encouraged." (38)

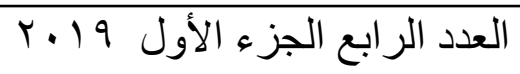

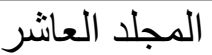


International Organizations and the Promotion of Gender Political ...

Dr. Nihal Shimy Abdel Fattah El-Shimy

Model of Gender Equality in Egypt: Improving Livelihoods of Women and securing rights:

The UN Women Rights and Improving Livelihoods for Women, aims to contribute to 3 key areas:

Key area 1: "Increased leadership and Participation of Women in the Public Sphere:

This program focuses on the abilities of women to access their right as equal citizens and their civic engagement. Millions of poor women in Egypt cannot exercise their rights as citizens without birth certificates and identity cards. (39)

Key Area 2: Increased Security, Autonomy and Economic Security of Marginalized women in rural areas /Upper Egypt. This area focuses on expanding economic opportunities for girls and women between the age of 18 and 45, and ensuring sustainable sources of income for them. 8000 poor women from five governorates ( Beheira, Sharkeya, Beni Suef, Assuit and Minya) will directly benefit from the program as they will have access to financial services such as schemes of micro credit and saving, and non financial services such as business development, access to markets and advisory services. Also, the indirect beneficiaries, basically dependent family members of the selected poor women, will be approximately 18,000 people. On the other

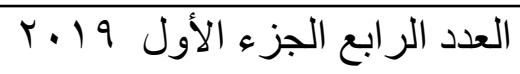

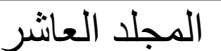


International Organizations and the Promotion of Gender Political ...

Dr. Nihal Shimy Abdel Fattah El-Shimy

hand, regional selections depend on planned or existing government projects. (40)

Key Area 3: To reduce Violence against girls and Women in Public: In Egypt, girls and women who live in cities, frequently experience a higher risk of exposures to different types of violence, which include rape and sexual harassment. This threatens women's rights as human beings and limits their freedom and feelings of security and safety. Thus, the basic aim of the safe cities is to furnish the concerned institutions in the country with the knowledge and skills to prevent and respond to public violence against girls and women. Therefore, it aims to protect women and girls from all types of violence as specified by the model of safe cities that will be implemented within the region of Greater Cairo and the urban areas of Qalyubiya and Giza. The Safe Cities is an attempt to positively contribute to ending violence against girls and women. Moreover, it also seeks to empower communities through youth and women leadership at grass roots level. " (41)

Moreover, the program seeks to achieve a long-term transformative impact in the way urban safety is conceptualized, moving beyond crime prevention to broader notions of tolerance, co-existence and non-discrimination stemming from a deepened understanding of how the use of, and access to, public spaces relates to citizens' rights, equality and participation.

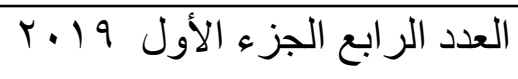

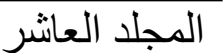


International Organizations and the Promotion of Gender Political ...

Dr. Nihal Shimy Abdel Fattah El-Shimy

Another program is Gender Responsive National Planning and Budgeting, which is a joint program between the Ministry of Finance, UN Women, Ministry of Planning, the Institute of National Planning and the National Council for Women. This initiative intends to advance gender equality and fulfill women's rights. In the meantime, it identifies and reflects required interventions in order to address gaps between gender in the local government plans, policies and budgets. It also seeks to analyze the differentiated gender impact on the allocation of local resources and development assistance. This program has succeeded to provide training opportunities inside the Ministry of Finance for women to calculate, track and evaluate local budgets and to make policy recommendations concerning equal opportunities for women in the budget.

In addition to the above, the Fund of Human Security Trust plays a very important role in human security, with special emphasis on groups such as youth and women. The fund seeks to create better opportunities of employment as well as increased employability of the labor force and the activities to develop social capital of society and consolidate inclusiveness and cohesion. In the meantime, UN Women continues to work on empowering poor women who have the potential to become

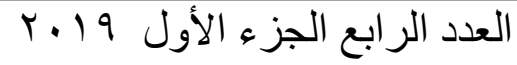

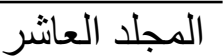


International Organizations and the Promotion of Gender Political ...

Dr. Nihal Shimy Abdel Fattah El-Shimy

entrepreneurs, but are traditionally left out from access to financial services. (42)

The Role of Egypt Network for Integrated Development "ENID", (Achievements from 2012-2016)

This UNDP project began in 2012 under the Ministry of International Cooperation. Also, it registered at the Ministry of social Solidarity, as a non- profit foundation in 2016. The vision of ENID is to "Contribute to the Global SDGs and National SDS Egypt vision in 2030 Towards Poverty Alleviation, Gender equality and Children Well Being." (SWOT p. 1) Their vision is gender equality, children well being and poverty alleviation in Upper Egypt. Their mission is basically to empower impoverished women and youth socially and economically in Rural Upper Egypt. ENID's main target is Qena, because of high poverty, high fertility rate, and low economic participation of women. According to studies and analysis made by ENID, there are high employment potentials in Qena, but there are areas of strengths, weaknesses, opportunities and threats. Examples of strengths are labor intensive activities that easy to introduce, and high employment potentials. Moreover, gender education and employment reduce the fertility rate and improve the nutrition and well being of children. The weaknesses are basically limited

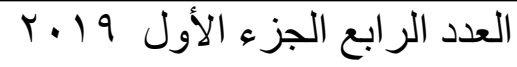
المجلد العاشر 
International Organizations and the Promotion of Gender Political ...

Dr. Nihal Shimy Abdel Fattah El-Shimy

skills, difficult access to financial resources, lack of market and business information as well as the complicated and bureaucratic procedures. In addition to that markets are found to be based against self employed women, due to the widespread illiteracy and low skills as well as the conservative culture found in Upper Egypt. The main opportunities have to do with wood industries because there is a high potential for local and export markets. These industries provide women with great advantages. There is also an increasing number of development NGOs in the south, which is a stepping stones e towards empowerment of youth and women. The main threats, however, are the fear of harassment which affects many women's decision to accept jobs found far from their homes, late working hours, and dominant male workers. Also, a major obstacle is trying to convince society with the issue of girls' work. (43) In its attempts to overcome some of the above problems, El NIDA found the following (I's:)

1. Innovation: by introducing new technology, new products and new markets.

2. Integration: by having sectoral interventions in basic services, and making partnership with leaders of the community and NGOs, local and central government, as well as grass roots groups' representatives.

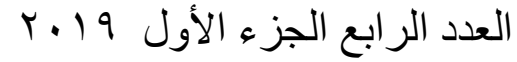

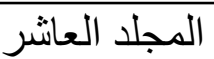


International Organizations and the Promotion of Gender Political ...

Dr. Nihal Shimy Abdel Fattah El-Shimy

3. Inclusion of the community by means of needs assessment surveys to identify options as well as priorities, participation (whether cash or in any form), and ownerships (Households or NGOs) to ensure sustainability. (44) In their literacy classes, attempts are made to empower marginalized women. While 593 women are registered in those classes, 493 actually graduated after passing the standard literacy tests. Afterwards, 363 women joined cut and sew training workshops, while 313 graduated from them. (45)

\section{ENID's Achievements in Gender Equality:}

1. OVOP/Apprenticeship: ELNIDA established one village One Product Model in 26 villages in Qena based on Japanese models. More than 26 of these villages produce handicrafts and are earning a regular income. Until 2016, 1044 beneficiaries were trained in the various workshops of ENID (64 men and 980 women). This means that $94 \%$ are women. (46)

Benefits of OVOP are shared technology and markets to provide more product orders at low costs. Also, it resulted in more job opportunities and competition to ensure equality. Examples of handicrafts are wood tuning and Arabesque,

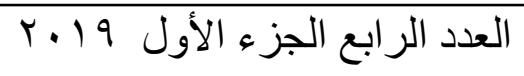$$
\text { المجلد العاثر }
$$ 
International Organizations and the Promotion of Gender Political ...

Dr. Nihal Shimy Abdel Fattah El-Shimy

carpentry, Khayameia, and oriental painting, professional painting, jewelry and fashion accessories, serma embroidery...etc.

2. Entrepreneurship and Financial training: Basic business management and basic financial and economic literacy training are offered. There are also programs for technical know how and skills. Moreover, EINIDA trained 30 university students on soft skills and entrepreneurship with curriculum tailored to their needs. (47) Achievements- policy and communication:

1. Influence local and national policies based on its lessons learnt.

2. Engage policy makers in best practice interventions on the field level.

\section{The Role of US Aid in the empowerment of Egyptian Women:}

For almost four decades, Americans have partnered with Egyptians to establish an environment where all different groups in Egypt, including minorities and women may lead productive, healthy lives. "totaling nearly $\$ 30$ billion since 1978, has directly and fundamentally supported gains such as a reduction in infant and maternal mortality rates, improvement in reading ability in 
International Organizations and the Promotion of Gender Political ...

Dr. Nihal Shimy Abdel Fattah El-Shimy

the early grades, and an increase in marketable skills - leading to jobs and lasting prosperity in Egypt." (48) Dr. Mary C. Ott, USAID Mission Director in Egypt said that "Entrepreneurship plays a significant role in driving economic growth and job creation," Therefore, "USAID is working to build the entrepreneurial capacity of women to develop businesses that will generate income for their families and to drive economic growth in Egypt."(49) The American government by means of the USAID supports employment and entrepreneurs creation, and thus support economic development. Until 2014, "USAID has helped launch 63 start-up companies in Egypt - 18 of which are owned by women - and helped provide new or better full-time employment for over 40,000 people and short-term jobs for another 20,000 workers." (50)

The IMF declared that the raising of the labor force participation rate of female to the male level, along with access to opportunities of employment would result in an increase of the GDP by almost $34 \%$. The USAID, in partnership with the private sector and the Egyptian government has several activities planned to improve the skills of women as well as their participation in micro as well as small and medium enterprises. (51) USAID works with the Egyptian government to decrease the gender gap across a number of sectors and activities, which include the removal of obstacles to women's economic

المجلد العاثر


International Organizations and the Promotion of Gender Political ...

Dr. Nihal Shimy Abdel Fattah El-Shimy

participation, dealing with violence against women as well as issues of harassment, and trying to reduce the gender enrollment gap in all education levels, including the improvement of girls in Science, Technology, Engineering and Mathematics (STEM) (52) Therefore, USAID, in partnership with the private sector and the Government, has some activities aiming to upgrade the skills and rate of participation of Egyptian women in the labor force, and abolish constraints and obstacles to their economic participation in micro, small and medium size enterprises.

A new era of gender work was launched in March 2012 concerning policies of female empowerment and gender equality world wide. The USAID believes that these goals are key strategies that aim to eliminate extreme poverty.

Some key themes focus on the increased access women should have to control and own resources such as property, land, financial tools...etc. Another key theme has to do with increased voice and choice which includes the ability of women to speak up for their needs in order to help to shape and form economic policies, and to have decision making power at all levels which include household, national and international levels. The final theme deals with well being and dignity, and this includes good nutrition and health, a better education and work life balance,

العدد الرابع الجزء الأول 9 1 •

المجلد العاثر 
International Organizations and the Promotion of Gender Political ...

Dr. Nihal Shimy Abdel Fattah El-Shimy

freedom from violence based on gender and all forms of improved economic opportunities. (53)

A partnership between USAID and the Egyptian government has been initiated in Egypt to promote girls of 10 to 14 years as leaders in their communities by:

1. The cultivation of opportunities to exercise skills of leadership

2. The creation of public private partnerships to encourage leadership of girls

3. The enhancement of global knowledge to promote and implement the leadership of programs (54)

In the meantime, Violence against women is a major violation to human rights that undermines the efforts to attain sustainable growth. Therefore, USAID cooperates with the local communities in order to decrease the harmful traditional practices of bride price, bride abduction and early marriage, especially of young girls in rural areas. In addition to that, with the enforcement of legal rights, women may access property and land ownership, education, financial services, fair employment as well as other services which can reduce their vulnerability to abuse or exploitation. (55)

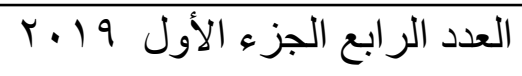

المجلد العانشر 
International Organizations and the Promotion of Gender Political ...

Dr. Nihal Shimy Abdel Fattah El-Shimy

Moreover, a major component of Strengthening Entrepreneurship and Enterprise Development (SEED) of USAID is to provide services of business development to assist women begin new businesses, and have new jobs. The (WISE) project, short for The Workforce Improvement and Skills Enhancement concentrates on developing skills by providing training for teachers in technical schools, with a special focus on youth and women. In addition to that, the six hundred scholarships have been provided by USAID since 2014 to both female graduate and undergraduate students to study in the fields of engineering, science and business. USAID recognizes the importance of education to empower women and girls, and therefore, works with the Egyptian government to encourage equal access to good education and to ensure successful learning outcomes. The USAID has attempted to provide equal opportunities for professional development and training to both female and male teachers in public schools. Not only that, but there are awarded scholarships granted by USAID to women study in the master's program in of business administration and undergraduate degree in American universities in the United States.(56)

Also the USAID supports programs that assist to strengthen the self confidence of women and develop their skill

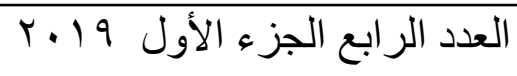

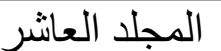


International Organizations and the Promotion of Gender Political ...

Dr. Nihal Shimy Abdel Fattah El-Shimy

in negotiations and network building. Such programs concentrate on empowering women to recognize, prioritize and take action that may address their needs. Education is believed to be a very powerful tool to reduce poverty and readdress inequality, improve social well being and health and create the basis for sustained economic growth.

Furthermore, the USAID is attempting to strengthen women's managerial and technical skills and encourage them to participate in societies and develop coordination among and between local organizations in order to reduce gender based violence $(\mathrm{GBV})$. Some activities were made by the USAID in 2008 to support girls and women in the areas of political participation and leadership, economic opportunities and entrepreneurship, education, legal rights, trafficking in persons, gender based violence and AIDS and HIV. (57) In 2009, the USAID made the first study on the issue of violence against women in Egypt, and in the year 2010, the USAID assisted the National Council for Women plan a national framework aiming at combating violence against women. Also, the USAID in 2010 assisted the National Council for Women to make a strategy to combat violence against women. Not only that, but in June 2014, the country amended its Penal Code to consider sexual harassment a crime. This amendment was in fact the result of the

$$
\text { العدد الرابع الجزء الأول } 9 \text { 1. }
$$$$
\text { المجلد العاثر }
$$ 
International Organizations and the Promotion of Gender Political ...

Dr. Nihal Shimy Abdel Fattah El-Shimy

coordination efforts made by the USAID between the Egyptian government and the civil society. By 2015, this plan became the basis for the country's strategy to combat violence against women. (58)

An initiative launched in 2014 was made by the U.S. Egypt Higher Education to provide many undergraduate scholarships to the best Egyptian universities for talented students who are underprivileged in various fields important for sustained economic growth of their country. Also, the initiative supports scholarships for females to go to American universities for undergraduates in technology, engineering, science and math, and graduate degrees in the field of business. In addition to that, the USAID is joining the U.S. National Academy of Sciences to increase the capacity of science and technology institutions in Egypt. (59)

The initiative of U.S. Egypt Higher Education has several components of scholarship that will contribute to the country's economic growth. Moreover, there is a project that provides scholarships to attend Egyptian females to pursue 62 undergraduate degrees and 98 MBAs in fields like Science, technology, Math in the United States so as to create a cadre of trained women leaders. (60)

العدد الرابع الجزء الأول 9 1 •

المجلد العاثر 
International Organizations and the Promotion of Gender Political ...

Dr. Nihal Shimy Abdel Fattah El-Shimy

There are also Fulbright scholarships to be given to 335 Egyptian students for programs of Master's degree in the U.S. in studies that are critical and important to Egypt's economic development. After graduation, these people are expected to go back to their country to join the private and public sectors, qualified for leadership roles. In addition to that, USAID also establishes centers of career development to help construct the ability of public universities to provide employability skills and career guidance. (61)

Thus, the programs of USAID helps build the self confidence of women, develop their network and negotiate building skills and identify support and information sources. In fact, such programs concentrate on the empowerment of women to prioritize, identify and take action. The USAID is also aiming at strengthening the technical and managerial skills of women and encourage them to participate in their societies and improve all forms of coordination among local organization in order to control and decrease gender based violence.

\section{Conclusion:}

As previously mentioned, gender discrimination against women is still a strong negative force in many countries including Egypt. Women's Political participation in Egypt is still

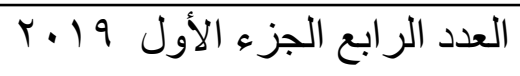$$
\text { المجلد العانشر }
$$ 
International Organizations and the Promotion of Gender Political ...

Dr. Nihal Shimy Abdel Fattah El-Shimy

limited as they confront continuous challenges in that respect and many women do not enjoy their full human rights because of poverty, inequality, violence and discrimination.

Although many women in Egypt still lack all forms of national identification, there has been an increase in women's political participation after January 2011. Women in Egypt have played an important role in the shaping of the political realities of the country in the last six years. In fact, Egyptian women believed that the 2011 revolution was a great chance to put an end to the negative stereotyping that has been linked to the role of women in society. Egyptian women thought that the revolution of 2011 marked an end to all negative stereotyping lined to women's role in society. "The Arab Spring has once more revived women's aspirations in claiming their full rights and being an active actor in shaping the policies and the future of their countries."(62) Therefore, the political life in Egypt passed through many changes which have led to high expectations in regards to women's rights. The government has cooperated with institutions of civil society and the international community together to empower women.

Despite that, there is still several areas of concern, and there is a special need to get national and international partners accelerate the progress towards equality of gender and women

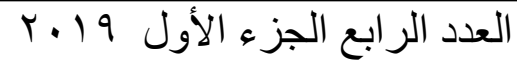

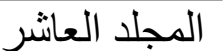


International Organizations and the Promotion of Gender Political ...

Dr. Nihal Shimy Abdel Fattah El-Shimy

empowerment. Therefore, international organizations including UNDP, UN Women and USAID believe Egyptian women remain disproportionately harmed by discrimination, poverty and exploitation, and thus attempt to collaborate with government agencies to narrow gender gap and empower women. The discrimination of gender implies that women can be in insecure jobs with low wages, and constitute only a very small minority of those who hold senior positions. This limits women's participation in shaping social and economic policies. Therefore, international agencies advocate gender equality as they strongly believe that the economic empowerment of women in general and Egyptian women in particular can set a direct path towards the eradication of poverty, equality of gender and total economic growth. (63) In other words, to ensure economic growth in Egypt, it is essential to empower women and integrate them as active participants in the country's economy.

Therefore, the researcher believes that education is very important in the whole process of empowerment. In other words, without good education, Egyptian women will not be aware of their critical role, especially after the 2011 revolution. Actually, women can practice a new role, and this is the real stimulus to push scientific, social and economic wheels forward.

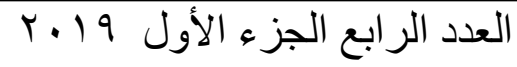

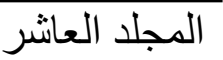


International Organizations and the Promotion of Gender Political ...

Dr. Nihal Shimy Abdel Fattah El-Shimy

Thus, for Egypt to prosper there is an urgent need to ensure gender equality in all areas including nutrition, health and equal chances in education and employment. Although some steps have been taken to narrow the gap, especially in terms of female literacy as well as education access, the increase is marginal. The improvement of the role of women in all aspects in general and political participation in particular can have great impacts on women's aspirations and improve their well being in the coming period. Since, a significant gender gap still persists in all indicators, a call is made to reduce gender disparities and ensure that women's voices are heard within the civil society, government institutions and the private sector. They should be able to engage and participate equally in dialogue and the process of decision making. (64)

Women are entitled to participate in all political processes that may affect them or may affect their families or societies. Nations that have more female's participation as well as more leadership in political parties and civil society tend to be more responsive, egalitarian, inclusive and democratic. However, women are still absent from local and national bodies of decision making, and are excluded from political processes. From violence and discrimination to a lack of resources and support, women face many challenges and problems to participation in the

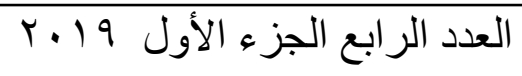

$$
\text { المجلد العاثر }
$$


International Organizations and the Promotion of Gender Political ...

Dr. Nihal Shimy Abdel Fattah El-Shimy

political and civic life of their countries. Thus, the empowerment of women and strengthening their rights and political participation are major to achieve gender equality. Not only that, but the increase of women's political participation and leadership can guarantee the acknowledgement of women's needs by the decision makers. In other words, the increase of the role of women in the decision making process of the country can have a direct effect on the strategic planning of the nation and may integrate the major societal challenges of women in the development of the whole country. (65) In her concession speech in 2016, Hilary Clinton encouraged girls to believe in themselves. She said: "To all the little girls who are watching, never doubt that you are valuable and powerful and deserving of every chance and opportunity in the world to pursue and achieve your own dreams." (66)

\section{Recommendations:}

1. To place women empowerment at the center of development plans.

2. To make policies and take actions ies make policies and take actions that guarantee universal access to women's rights in the spheres of health, education, business, and all forms of gender equality. 
International Organizations and the Promotion of Gender Political ...

Dr. Nihal Shimy Abdel Fattah El-Shimy

3. Eliminate all forms of discrimination under the law.

4. Promote equal access for women like men, to opportunities and resources.

5. Promote and encourage the hearing of women's voices in decision making at all levels.

6. Establish more centers to enhance and empower women and attempt to:

a. Create safe space for women to gather with other women and talk about issues like gender equality.

b. Support independence and mobility

c. Reduce illiteracy rate between girls and women by teaching them to read.

d. Promote savings and income by joining savings cooperatives which allow women to invest money and take turns receiving micro loans to begin micro business or invest in education for their children.

e. Teach job skills like sewing through training programs.

f. Increase self esteem and confidence by helping women to speak in front of groups and share ideas.

g. Encourage women's participation in decision making

h. Impact health by establishing health information and services at centers on health care, and inform women about family planning, violence and reproductive rights. 
International Organizations and the Promotion of Gender Political ...

Dr. Nihal Shimy Abdel Fattah El-Shimy

i. Build networks: by building social networks, women have more support and greater opportunities to effect change in their societies.

j. Provide leadership training for women to increase their presence in the public sphere.

7. Get boys and men engaged in the dialogue as they are part of the solution.

8. Advance the labor rights of women and invest in their participation in the labor force. This can close the economic participation gap between males and females and could increase Egypt's GDP.

9. Address the important contribution and time drain of care work like elder care, child care, washing clothes, preparing food...etc.

10.Promote property and land ownership by women.

11.Prioritize the financial inclusion of women

12.Enable females to take on more roles in leadership in the various business levels because this can result in better financial performance.

13.Invest in the capacity building of women to better equip them with better skills and achieve economic empowerment.

14.Advocate and encourage men in the economic empowerment of women as well as activities of equality 
International Organizations and the Promotion of Gender Political ...

Dr. Nihal Shimy Abdel Fattah El-Shimy

programming. This can result in better family dynamics, improved relations between partners, more knowledge, better and understanding of laws of gender equality.

15.More positive participation of men to share activities of household and take care of children.

16.Form a dialogue with men to assist change gender beliefs and norms on the role of women in society.

17.Engage men to discover and explore the basis of their gender norms, masculinity ideas and biases.

18. Advocate mutual respect, cooperation and reliability between women and men in the economic sphere, and which can have positive effects in other areas.

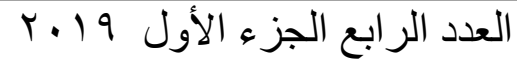
المجلد العاثر 
International Organizations and the Promotion of Gender Political ...

Dr. Nihal Shimy Abdel Fattah El-Shimy

\section{End Notes:}

1. UNITED NATIONS POPULATION INFORMATION NETWORK (POPIN)

UN Population Division, Department of Economic and Social Affairs, with support from the UN Population Fund (UNFPA). Guidelines on Women's Empowerment http://www.un.org/popin/unfpa/taskforce/guide/iatfwemp.gdl.html

2. IBID., (UNFPA).

3. IBID., (UNFPA).

4. IBID., (UNFPA).

5. Amy C. Alexander \& Christian Welzel, Empowering Women: Four Theories Tested on Four Different Aspects of Gender Equality, 2005. https://www.democracy.uci.edu/files/docs/conferences/grad/alexander.pd $\underline{\mathrm{f}}$

6. Sandra Halperin, Development theory .Economics and Political Science, 2013. https://www.britannica.com/topic/development-theory

7. Ashley Crossman, Feminist Theory in Sociology, Ausgust 11, 2017. https://www.thoughtco.com/feminist-theory-3026624

8. Ashley Crossman, Understanding Conflict Theory, August 4, 2017. https://www.thoughtco.com/conflict-theory-3026622

9. Ranya Khalifa, Gender Equality Still Distant Dream for Egypt Women, April 3, 2012.

http://middleeastvoices.voanews.com/2012/04/viewpoint-genderequality-still-distant-dream-for-egypt-women-59380/\#ixzz4yEqg5oKi

\section{USAID SUPPORTS GENDER EQUALITY AND WOMEN'S EMPOWERMENT,}

March, 2009.

https://www.usaid.gov/news-information/fact-sheets/usaid-supports-genderequality-and-womens-empowerment 11. UN Women. Arab States/North Africa.

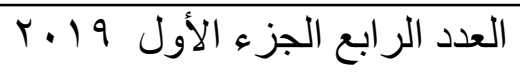


International Organizations and the Promotion of Gender Political ...

Dr. Nihal Shimy Abdel Fattah El-Shimy

http://arabstates.unwomen.org/en/countries/egypt

12.Op.Cit.,Khalifa, 2012.

13. OP.Cit., UN Women. Arab States/North Africa.

14. Amany Khodair,\& Bassant Hassib, B, Women's Political Participation in Egypt: The Role of The National Council for Women, International Journal of Political Science and Development Vol. 3(7), pp. 326-337, July 2015 DOI:

https://papers.ssrn.com/sol3/papers.cfm?abstract_id=2861469

15. IBID., Khodair, 2015.

16. Hassan Mozn, Women's Rights in the Aftermath of the 2011 Revolution, file:///C:/Users/SARY/Downloads/Documents/euspring_paper_5_womans_r ights_in_egypt.pdf

17. IBID., Mozn.

18. IBID., Mozn.

19. IBID., Mozn.

20 OP.Cit., Khodeir, 2015.

21. OP.Cit., Khodeir, 2015.

22. Khaled Ashmhawy, The Social and Economic Empowerment of Women in Egypt: Towards a New Development Paradigm, 2016.

file:///C:/Users/SARY/Downloads/Documents/PB36_socioeconomic_empower ment 2.pdf

23. OP.Cit., USAID, 2009.

24. OP.Cit., Mozn.

25. Goals of the UNDP, http://www.undp.org/content/undp/en/home/sustainabledevelopment-goals/goal-5-gender-equality.html.

26. IBID., Goals of the UNDP.

27. OP.Cit., Ashmhawy, 2016.

28.Elise YOUNG \& ANDREA BERTONE, USAID Women's Economic Empowerment and Equality Assessment Report, 2016.

HTTPS://WWW.FHI360.ORG/SITES/DEFAULT/FILES/MEDIA/DOCUMEN TS/WOMENS-ECONOMIC-EMPOWERMENT-ASSESSMENT.PDF

29. Reham. Mokbel, New ad campaign seeks to empower Egyptian women, 2016.

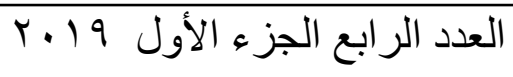$$
\text { المجلد العاثر }
$$ 
International Organizations and the Promotion of Gender Political ...

Dr. Nihal Shimy Abdel Fattah El-Shimy

https://www.al-monitor.com/pulse/en/originals/2016/07/egypt-tv-campaignwomen-empowerment-domestic-violence.html

30. OP.Cit., UN Women Arab States / North Africa.

31. OP.Cit., UN Women Arab States / North Africa.

32. UN Women, Egyptian Women are Key to driving Egypt's growth, 2016. http://www.unwomen.org/en/news/stories/2016/2/egyptian-women-are-key-todriving-egypts-growth.

33. IBID., UN Women, 2016.

34. UN Women, Women's Economic Empowerment Investing in the Future Why Invest in Women?

https://www.thevillagelink.org/women-

empowerment?gclid=EAIaIQobChMI8qTg-

8OilwIVRpUbCh0Leg8REAAYBCAAEgJ_8vD_BwE

35. IBID., UN Women, Women's Economic Empowerment.

36. OP.Cit, UN Women, 2016.

37. OP.Cit., UN Women Arab States / North Africa.

38. OP.Cit., UN Women Arab States / North Africa.

39. OP.Cit., UN Women Arab States / North Africa.

40. OP.Cit., UN Women Arab States / North Africa.

41. OP.Cit., UN Women Arab States / North Africa.

42. OP.Cit., UN Women Arab States / North Africa.

43. The Role of Egypt Network for Integrated Development "ENID”, 2017.

44. IBID., ENID, 2017.

45. IBID., ENID, 2017.

46. IBID., ENID, 2017.

47. IBID., ENID, 2017.

48. USAID. STRENGTHENING WOMEN'S RIGHTS AND POLITICAL PARTICIPATION, . HIGHER EDUCATION, UPDATED NOVEMBER 7, 2017.

HTTPS://WWW.USAID.GOV/EGYPT/HIGHER-EDUCATION

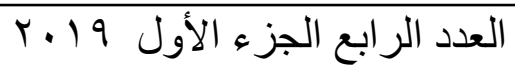


International Organizations and the Promotion of Gender Political ...

Dr. Nihal Shimy Abdel Fattah El-Shimy

49. USAID Promotes Women and Entrepreneurship, UNDP, 10, 2014. https://www.usaid.gov/egypt/press-releases/apr-10-2014-us-governmentpromotes-women-and-entrepreneurship

50. IBID., USAID, 2014.

51. OP.Cit., 2009.

https://www.usaid.gov/news-information/fact-sheets/usaid-supports-genderequality-and-womens-empowerment

52. OP.Cit.,2009.

53. Elise YOUNG \& ANDREA BERTONE, USAID Women's Economic Empowerment and Equality Assessment Report, 2016.

HTTPS://WWW.FHI360.ORG/SITES/DEFAULT/FILES/MEDIA/DOCUMEN TS/WOMENS-ECONOMIC-EMPOWERMENT-ASSESSMENT.PDF

54. OP.Ci., USAID, 2009.

55. OP.Cit., USAID, 2009.

56. OP.Cit., USAID, 2009.

57. OP.Cit., USAID, 2009.

58. OP.Cit., USAID, 2009/

59. OP.Cit., USAID, 2017.

60. OP.Cit., USAID, 2017.

61. OP.Cit., USAID, 2017.

62. OP.Cit., Khodair, 2015.

63. UN Women, Arab states/North Africa.

64. OP.Cit., Ashmahwy, 2016.

65. OP.Cit., Ashmahwy, 2016.

66. Lauren Fisher, 35 Empowering Feminist Quotes from Inspiring Women.

http://www.harpersbazaar.com/culture/features/a4056/empowering-femalequotes/

\section{References:}

1. Adams, D. (2005), A Definition of Culture of Peace.

http://www.culture-of-peace.info/copoj/definition.html

2. Alexander A., and Welzel C. (2005), Empowering Women: Four Theories Tested on Four Different Aspects of Gender Equality. 
International Organizations and the Promotion of Gender Political ...

Dr. Nihal Shimy Abdel Fattah El-Shimy

https://www.democracy.uci.edu/files/docs/conferences/grad/alexander.pd $\underline{\mathrm{f}}$

3. Aspden, Rachel. (2016). Egypt's gender inequality has a price the country can't afford.

https://www.thenational.ae/opinion/egypt-s-gender-inequality-has-aprice-the-country-can-t-afford-1.209886

4. Ashmhawy, Khaled. ( January, 2016). The Social and Economic Empowerment of Women in Egypt: Towards a New Development Paradigm.

file:///C:/Users/SARY/Downloads/Documents/PB36_socioeconomic_em powerment_2.pdf

5. Black, Robyn. Breaking Down Stereotypes of Egyptian Women:

Examining Traditional Private versus Western Influenced Public Gender

Roles.

file:///C:/Users/SARY/Downloads/12748-31451-1-SM.pdf

6. Correll, Shelley. (2016). An Introduction to the social Psychology of Gender.

file:///D:/books\%20downloaded\%202016/Soc. $\% 20201 /$ Soc\%20201\%20 Social\%20Psychology\%20of\%20Gender.pdf

7. Crossman, Ashley. (August 4, 2017), Understanding Conflict Theory . https://www.thoughtco.com/conflict-theory-3026622

8. Crossman, Ashley. (August 11, 2017)., Feminist Theory in Sociology https://www.thoughtco.com/feminist-theory-3026624

9. Grown, Caren. (2005), Taking Action: Achieving Gender Equality and Empowering Women. U.N Millennium Project.

chttps://books.google.com.eg/books?hl=en\&lr=\&id=dP-

SRE4WCJEC\&oi=fnd\&pg=PR3\&dq=recommendations+for+empoweri ng+women\&ots=OpMc0AzOAQ\&sig=1XIWR17VqRIs-

T1So8JeDrQQv2I\&redir_esc $=y \# v=$ onepage $\& q=$ recommendations $\% 20 \mathrm{f}$ or\%20empowering\%20women\&f=false

10. Fisher, Lauren. 35 Empowering Feminist Quotes from Inspiring Women.

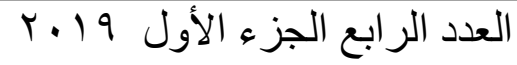

المجلد العاشر 
International Organizations and the Promotion of Gender Political ...

Dr. Nihal Shimy Abdel Fattah El-Shimy

http://www.harpersbazaar.com/culture/features/a4056/empoweringfemale-quotes/

11. Halperin, Sandra. (2013). Development theory .Economics and Political Science. https://www.britannica.com/topic/development-theory

12. Hassan, Mozn. Women's Rights in the Aftermath of the 2011 Revolution.

file:///C:/Users/SARY/Downloads/Documents/euspring_paper_5_womans_r ights_in_egypt.pdf

13. Ibrahim, Baher. (2010). The struggle for equality in Egypt. https://www.theguardian.com/commentisfree/2010/apr/07/equality-struggleegypt-women

14. Khodair, Amany A. and Hassib, B. (2015). Women's Political Participation in Egypt: The Role of The National Council for Women, International Journal of Political Science and Development Vol. 3(7), pp. 326-337, July 2015 DOI:

https://papers.ssrn.com/sol3/papers.cfm?abstract_id=2861469

15. Khalifa, Ranya. (April 3, 2012). VIEWPOINT: Gender Equality Still Distant Dream for Egypt Women.

http://middleeastvoices.voanews.com/2012/04/viewpoint-genderequality-still-distant-dream-for-egypt-women-59380/\#ixzz4yEqg50Ki http://middleeastvoices.voanews.com/2012/04/viewpoint-gender-equalitystill-distant-dream-for-egypt-women-59380/

16. Megahed, Horeya. (2014). Egyptian Women and the New Constitution.

http://womenalliance.org/egyptian-women-and-the-new-constitution

17. Mokbel, Reham. (2016). New ad campaign seeks to empower

Egyptian women.

https://www.al-monitor.com/pulse/en/originals/2016/07/egypt-tvcampaign-women-empowerment-domestic-violence.html 
International Organizations and the Promotion of Gender Political ...

Dr. Nihal Shimy Abdel Fattah El-Shimy

18. Wilson, Elizabeth Ann. (2014). Empowering Women-A Series of Articles About the Surge in and Fragmentation of Mid-20th-Century American Feminist Theory. Article 1: Radical Notions, July 24,

2014.

http://journals.sagepub.com/doi/full/10.1177/2158244014543784

19. YOUNG, ELISE AND BERTONE, ANDREA. (FEBRUARY, 2016). USAID Women's Economic Empowerment and Equality Assessment Report

HTTPS://WWW.FHI360.ORG/SITES/DEFAULT/FILES/MEDIA/DO CUMENTS/WOMENS-ECONOMIC-EMPOWERMENTASSESSMENT.PDF

$\underline{\text { Sources from International Organiztions }}$

1. UNDP Gender Equality.

http://www.eg.undp.org/content/egypt/en/home/ourwork/gender-

equality/overview.html

2. UN Women. Arab States/North Africa

http://arabstates.unwomen.org/en/countries/egypt

3. USAID. (March, 2009), GENDER EQUALITY AND WOMEN'S

EMPOWERMENT

USAID SUPPORTS GENDER EQUALITY AND WOMEN'S

EMPOWERMENT

https://www.usaid.gov/egypt/gender-equality-and-womens-empowerment

4. UNDP, Gender equality.

http://www.eg.undp.org/content/egypt/en/home/ourwork/gender-

equality/overview.html

5.UNDP. Social, Economic and Legal Empowerment of Egyptian Women. http://www.eg.undp.org/content/egypt/en/home/operations/projects/genderequality/SocialEconomicLegalEmpowermentofWomen/

6.UNITED NATIONS POPULATION INFORMATION NETWORK (POPIN) UN Population Division, Department of Economic and Social Affairs,

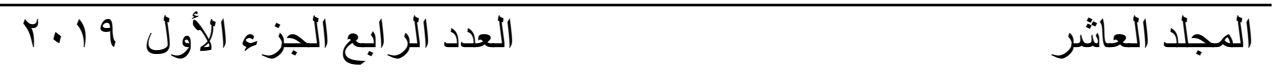


International Organizations and the Promotion of Gender Political ...

Dr. Nihal Shimy Abdel Fattah El-Shimy

with support from the UN Population Fund (UNFPA). Guidelines on Women's Empowerment

http://www.un.org/popin/unfpa/taskforce/guide/iatfwemp.gdl.html

7. UNDP, (April 10, 2014),. USAID Promotes Women and Entrepreneurship. https://www.usaid.gov/egypt/press-releases/apr-10-2014-us-governmentpromotes-women-and-entrepreneurship

8. Women's Economic Empowerment Investing in the Future Why Invest in Women?

https://www.thevillagelink.org/womenempowerment?gclid=EAIaIQobChMI8qTg-

8Oi1wIVRpUbCh0Leg8REAAYBCAAEgJ_8vD_BwE

\section{USAID SUPPORTS GENDER EQUALITY AND WOMEN'S EMPOWERMENT}

March, 2009.

https://www.usaid.gov/news-information/fact-sheets/usaid-supports-genderequality-and-womens-empowerment

10. USAID STRENGTHENING WOMEN'S RIGHTS AND POLITICAL

PARTICIPATION ( NOVEMBER 3, 2017). https://www.usaid.gov/what-wedo/gender-equality-and- ens-empowerment/addressing-gender-

programming/strengthening-womens

11. HIGHER EDUCATION. (November 7, 2017).

HTTPS://WWW.USAID.GOV/EGYPT/HIGHER-EDUCATION.

12. MENA Gender Equality Profile. (2011).

Status of Girls and Women in the Middle East and North Africa.

https://www.unicef.org/gender/files/Egypt-Gender-Eqaulity-Profile-2011.pdf

13. Hanlon, Kathryn. (23 Jan, 2017). Gender Inequality In Egypt. $\underline{\text { Current }}$ Events / Egypt.

The Organization for World Peace

https://theowp.org/gender-inequality-in-egypt/

14. UN Women. (February, 2016), Egyptian Women are Key to driving Egypt's growth.

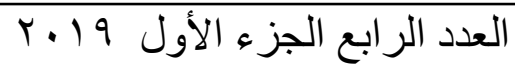$$
\text { المجلد العاثر }
$$ 
International Organizations and the Promotion of Gender Political ...

Dr. Nihal Shimy Abdel Fattah El-Shimy

http://www.unwomen.org/en/news/stories/2016/2/egyptian-women-are-key-todriving-egypts-growth.

15.USAID. (2016), GENDER EQUALITY AND WOMEN'S EMPOWERMENT

https://www.usaid.gov/egypt/gender-equality-and-womens-empowerment

16.UNITED NATIONS POPULATION INFORMATION NETWORK (POPIN)

UN Population Division, Department of Economic and Social Affairs, with support from the UN Population Fund (UNFPA).

http://www.un.org/popin/unfpa/taskforce/guide/iatfwemp.gdl.html

17.UN Women. (February 12, 2016). Egyptian Women are Key to driving Egypt's growth.

http://www.unwomen.org/en/news/stories/2016/2/egyptian-women-are-key-to-

driving-egypts-growth

18.The Role of Egypt Network for Integrated Development "ENID”, 2017.

19.USAID. STRENGTHENING WOMEN'S RIGHTS AND POLITICAL

PARTICIPATION (UPDATED NOVEMBER 7, 2017). HIGHER

EDUCATION.

HTTPS://WWW.USAID.GOV/EGYPT/HIGHER-EDUCATION

20.USAID. EGYPT. LAST UPDATED OCTOBER 13, 2017.

HTTPS://WWW.USAID.GOV/EGYPT

21.USAID ( FEBRUARY, 2016). WOMEN'S ECONOMIC

EMPOWERMENT AND EQUALITY ASSESSMENT REPORT.

HTTPS://WWW.FHI360.ORG/SITES/DEFAULT/FILES/MEDIA/DOCUMEN

TS/WOMENS-ECONOMIC-EMPOWERMENT-ASSESSMENT.PDF

العدد الرابع الجزء الأول 9 1 •r

المجلد العاثر 